\title{
Letter from England
}

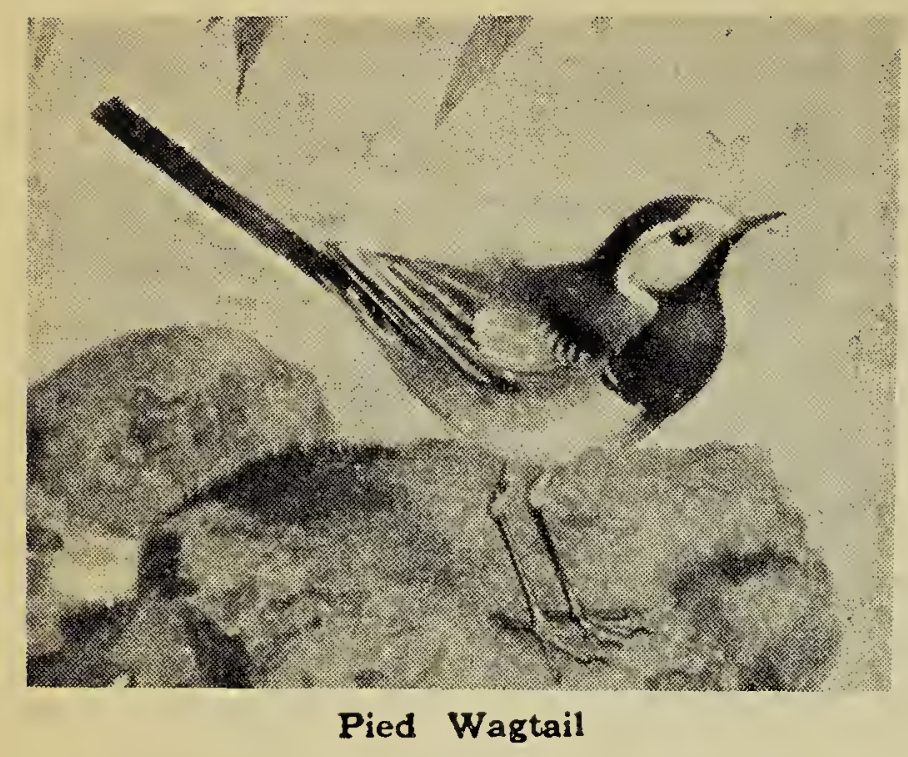

EDITOR'S NOTE: We enjoyed receiving this letter from England from Tim Dixon, the ardent English "birder" whom we met last June and invited to go with us to the SNHS meeting at Moose Mountain. Everyone who met Tim Dixon at the summer meet will agree that getting to know new and enthusiastic birders from other places is one of the real attractions of our summer get-together.

All our summer birds have gone but our winter birds have not arrived down here yet, except for a small flock of about 30 White-fronted Geese which I saw on the River Severn near the Wildfowl Trust. That was last Saturday (October 17, 1959) when I visited the Trust.with friends. As you probably know, it claims to be the largest collection of wildfowl in the world and it certainly is a wonderful place with most extensive grounds, many pools, pens, gazebos, etc., and innumerable birds. North America is quite well represented and I saw many of my favourite Canadian species with Wood Ducks especially plentiful.

Just around Wells, there is not too much surface water, so few water birds, but there are hills, valleys, and plenty of woods. In these woods are many of our typical speciesGreen Woodpeckers, Great Spotted Woodpeckers, and Nuthatches in goodly numbers, with Marsh Tits, Long-tailed Tits, Coal Tits, and Tree Creepers all pretty common. Of predators, Buzzard, Sparrow Hawk, and Kestrel are all common but all other species are very rare. A family you do not have is the wagtail group, and here there are many Pied Wagtails. They like lawn's and moist areas and can often be seen hunting for insects around the Moat. Sometimes there are five or six and they roost communally. I know of a roost of 40 odd in ivy on an old Unitarian chapel in my home town of Macclesfield. The Grey Wagtail-which many claim to be the most elegant bird on the British list-is also seen around the Moat. It is more solitary-it is quite rare to see more than two togetherand is seldom seen except near still or running water.

Another lovely bird seen around the Moat is the Kingfisher-quite a different sort of bird from the big Belted Kingfisher so familiar in Canada. Ours is no larger than a thrush, with arrow-straight flight and sharp call. No doubt one or two would nest locally.

Today I chanced to walk around the Moat and found that it had been temporarily drained so that only a small brook flowed down the middle of it. Here two Mute Swans were feeding and a Little Grebe was diving. Once the Little Grebe dived and reappeared just as some vegetable matter drifted downstream, with the result that it acquired a crown and necklace of the floating weeds and leaves.

Local owls are the Tawny and the Little. Lord Lilford introduced the Little Owl from the Continent many years ago, and since then it has spread throughout England and Wales and is common in many places. It has a shrill cry which it utters at dusk and is on the whole rather noisy. It would be about the size of a Screech Owl.

We had quite a good wader migration in Poole Harbour, many Redshank and Greenshank, a Spotted Redshank, 400+ Curlews, a Whimbrel, hundreds of Oyistercatchers, Dunlin, and Turnstones, and a Black-tailed Godwit, many Bar-tailed Godwits, and so on. On heaths nearby, I was very pleased to find again the very rare and local Dartford Warbler, and I twice saw a Marsh Harrier.

Coming across the North Atlantic on my way home I saw many Fulmars, Great Shearwater and Manx Shearwater, with hundreds of Gannets on Ailsa Craig and a nice flock of Roseate Terns near the Isle of Man. 